\title{
Front Matter: Volume 9213
}

, "Front Matter: Volume 9213," Proc. SPIE 9213, Hard X-Ray, Gamma-Ray, and Neutron Detector Physics XVI, 921301 (10 October 2014); doi:

$10.1117 / 12.2085360$

SPIE Event: SPIE Optical Engineering + Applications, 2014, San Diego, California, SPIE. United States 


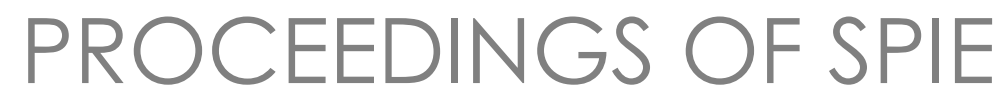

\title{
Hard X-Ray, Gamma-Ray, and Neutron Detector Physics XVI
}

\author{
Arnold Burger \\ Larry Franks \\ Ralph B. James \\ Michael Fiederle \\ Editors
}

18-20 August 2014

San Diego, California, United States

Sponsored and Published by

SPIE 
The papers included in this volume were part of the technical conference cited on the cover and title page. Papers were selected and subject to review by the editors and conference program committee. Some conference presentations may not be available for publication. The papers published in these proceedings reflect the work and thoughts of the authors and are published herein as submitted. The publisher is not responsible for the validity of the information or for any outcomes resulting from reliance thereon.

Please use the following format to cite material from this book:

Author(s), "Title of Paper," in Hard X-Ray, Gamma-Ray, and Neutron Detector Physics XVI, edited by Arnold Burger, Larry Franks, Ralph B. James, Michael Fiederle, Proceedings of SPIE Vol. 9213 (SPIE, Bellingham, WA, 2014) Article CID Number.

ISSN: 0277-786X

ISBN: 9781628412406

Published by

SPIE

P.O. Box 10, Bellingham, Washington 98227-0010 USA

Telephone +1 3606763290 (Pacific Time) · Fax +1 3606471445

SPIE.org

Copyright @ 2014, Society of Photo-Optical Instrumentation Engineers.

Copying of material in this book for internal or personal use, or for the internal or personal use of specific clients, beyond the fair use provisions granted by the U.S. Copyright Law is authorized by SPIE subject to payment of copying fees. The Transactional Reporting Service base fee for this volume is $\$ 18.00$ per article (or portion thereof), which should be paid directly to the Copyright Clearance Center (CCC), 222 Rosewood Drive, Danvers, MA 01923. Payment may also be made electronically through CCC Online at copyright.com. Other copying for republication, resale, advertising or promotion, or any form of systematic or multiple reproduction of any material in this book is prohibited except with permission in writing from the publisher. The CCC fee code is 0277-786X/14/\$18.00.

Printed in the United States of America.

Publication of record for individual papers is online in the SPIE Digital Library.

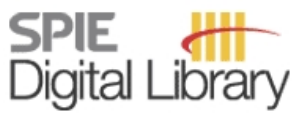

SPIEDigitalLibrary.org

Paper Numbering: Proceedings of SPIE follow an e-First publication model, with papers published first online and then in print and on CD-ROM. Papers are published as they are submitted and meet publication criteria. A unique, consistent, permanent citation identifier (CID) number is assigned to each article at the time of the first publication. Utilization of CIDs allows articles to be fully citable as soon as they are published online, and connects the same identifier to all online, print, and electronic versions of the publication. SPIE uses a six-digit CID article numbering system in which:

- The first four digits correspond to the SPIE volume number.

- The last two digits indicate publication order within the volume using a Base 36 numbering

system employing both numerals and letters. These two-number sets start with 00, 01, 02, 03, 04, 05, 06, 07, 08, 09, 0A, 0B ... 0Z, followed by 10-1Z, 20-2Z, etc.

The CID Number appears on each page of the manuscript. The complete citation is used on the first page, and an abbreviated version on subsequent pages. Numbers in the index correspond to the last two digits of the six-digit CID Number. 


\title{
Contents
}

\author{
vii Authors \\ ix Conference Committee \\ xiii Introduction
}

\section{SCINTILLATORS I}

921302 High energy resolution with transparent ceramic garnet scintillators (Invited Paper) [9213-1]

921303 High energy resolution scintillators for nuclear nonproliferation applications (Invited Paper) [9213-2]

921306 Triplet harvesting plastic scintillators with neutron-gamma pulse shape discrimination [9213-5]

\section{CZT I}

921308 Optimization of $\leq \mathbf{2 0 0} \mu \mathrm{m}$ pitch CZT detectors for future high-resolution $\mathrm{x}$-ray instrumentation in astrophysics (Invited Paper) [9213-7]

\section{NEUTRON DETECTORS}

9213 OB Improving neutron detection in semiconducting ${ }^{6}$ LilnSe2 (Invited Paper) [9213-10]

9213 OC Semiconductor neutron detectors using depleted uranium oxide (Invited Paper) [9213-11]

9213 OD Investigation of a Lithium Indium Diselenide detector for neutron transmission imaging [9213-12]

\section{DETECTOR MATERIALS I}

9213 OF CdTexSe1-x: a potential candidate for room-temperature radiation detector applications (Invited Paper) [9213-15]

$92130 \mathrm{G}$ Investigation of the current-voltage characteristics, the electric field distribution and the charge collection efficiency in $\mathrm{x}$-ray sensors based on chromium compensated gallium arsenide (Invited Paper) [9213-16]

$9213 \mathrm{OH} \quad$ Scintillator efficiency study with MeV x-rays (Invited Paper) [9213-17] 
$92130 \mathrm{~J}$ Advances in the growth of alkaline-Earth halide single crystals for scintillator detectors (Invited Paper) [9213-19]

9213 OK Toward a user's toolkit for modeling scintillator non-proportionality and light yield (Invited Paper) [9213-20]

$9213 \mathrm{OL} \quad$ Radiation response of inorganic scintillators: insights from Monte Carlo simulations (Invited Paper) [9213-21]

$92130 \mathrm{M}$ Search for improved-performance scintillator candidates among the electronic structures of mixed halides (Invited Paper) [9213-22]

9213 ON Strontium iodide instrument development for gamma spectroscopy and radioisotope identification [9213-23]

\section{DEVICES I}

9213 OT Review of current neutron detection systems for emergency response [9213-29]

9213 OU A dual-energy transmission detector for vehicle scanning using wavelength-shifting fibers [9213-30]

9213 OV Characterization of the ePix 100 prototype: a front-end ASIC for second-generation LCLS integrating hybrid pixel detectors [9213-31]

\section{CZT II}

9213 OY Chemical treatment of CdZnTe radiation detectors using hydrogen bromide and ammonium-based solutions [9213-34]

\section{DETECTOR MATERIALS II}

921312 Thin-film-based scintillators for hard x-ray microimaging detectors: the Scin ${ }^{\top A X}$ Project [9213-38]

921313 Oxidation/reduction reactions at the metal contact-TIBr interface: an x-ray photoelectron spectroscopy study [9213-39]

921314 Design and growth of lead selenoiodide semiconductors crystals for radiation detection [9213-40]

921315 Investigation of low leakage current radiation detectors on $\mathbf{n}$-type $\mathbf{4 H}$-SiC epitaxial layers [9213-41] 
921316 Development of an x-ray generator using a pyroelectric crystal for $x$-ray fluorescence analysis on planetary landing missions [9213-42]

921318 Xenon detector with high energy resolution for gamma-ray line emission registration [9213-44]

921319 Emergency OSL/TL dosimetry with integrated circuits from mobile phones [9213-45]

$92131 \mathrm{~A}$ Use of a position-sensitive multi-anode photomultiplier tube for finding gamma-ray source direction [9213-46]

\section{POSTER SESSION}

9213 1B The neutron detectors based on oxide scintillators for control of fissionable radioactive substances [9213-47]

9213 1C Spectroscopic response of Cd(Zn)Te radiation detectors with a Schottky diode [9213-48]

$92131 \mathrm{~F} \quad$ Recent progresses in scintillating doped silica fiber optics [9213-51]

$92131 \mathrm{G}$ Mechanisms of the passage of dark currents through $\mathrm{Cd}(\mathrm{Zn}) \mathrm{Te}$ semi-insulating crystals [9213-52]

$92131 \mathrm{H} \quad$ Purification of p-type CdTe crystals by thermal treatment [9213-53]

921311 Real time wide area radiation surveillance system (REWARD) based on 3d silicon and $(C D, Z N) T e$ for neutron and gamma-ray detection [9213-54]

$92131 \mathrm{~K} \quad$ Change in the bulk resistivity of CdZnTe with selected near IR light [9213-56]

$92131 \mathrm{~L}$ Characterization of high-resistivity CdTe and Cd0.92no.1Te crystals grown by Bridgman method for radiation detector applications [9213-57]

$92131 \mathrm{~N}$ Characterization of cadmium manganese telluride ( $\left.\mathrm{Cd}_{1-x} \mathrm{Mn}_{\mathbf{x}} \mathrm{Te}\right)$ crystals grown by the modified floating-zone method [9213-59]

9213 1P Photon crosstalk in pixel array for $\mathbf{x}$-ray imaging [9213-61] 
Proc. of SPIE Vol. $9213921301-6$

Downloaded From: https://www.spiedigitallibrary.org/conference-proceedings-of-spie on 26 Apr 2023 Terms of Use: https://www.spiedigitallibrary.org/terms-of-use 


\section{Authors}

Numbers in the index correspond to the last two digits of the six-digit citation identifier (CID) article numbering system used in Proceedings of SPIE. The first four digits reflect the volume number. Base 36 numbering is employed for the last two digits and indicates the order of articles within the volume. Numbers start with 00, 01, 02, 03, 04, 05, 06, 07, 08, 09, OA, OB...0Z, followed by 10-1Z, 20-2Z, etc.

Adhikari, Rajendra, OM

Ahle, L., 02

Amano, Yoshiharu, 16

Arnold, B., 14

Auxier, Jerrad Philip, OC

Baker, Stuart, $\mathrm{OH}$

Baumbach, T., 12

Beck, P. R., 02, 0J, ON

Beilicke, Matthias, 08

Bhattacharya, Pijush, OB, OJ

Bilheux, Hassina, OD

Biswas, Koushik, OM

Blaj, G., OV

Boatner, L. A., OJ, ON

Bolotnikov, Aleksey E., OF, 1C, 1G, 1H, IN

Brown, Kristina, $\mathrm{OH}$

Buliga, Vladimir, IK

Burger, Arnold, OB, OD, OJ, OM, ON, IK

Camarda, G. S., OF, $1 \mathrm{~N}$

Campbell, Luke W., OL

Cantone, Marie Claire, IF

Caragiulo, P., OV

Carini, G., OV

Cecilia, A., 12

Chaudhuri, Sandeep K., 15

Cherepy, Nerine J., 02, 0J, ON

Chernysheva, Irina $V_{\text {., }} 18$

Chiodini, Norberto, $1 \mathrm{~F}$

Cho, Gyuseong, IP

Choa, Fow-Sen, 14

Chung, Y.-S., 02

Chvala, Ondrej, OD

Cirignano, L., 13

Conway, A. M., 13

Couchaud, M., 12

Cui, Y., OF, IN

Cunningham, Taylor, OC

Curtis, Alden, $\mathrm{OH}$

Danielson, Jeremy, $\mathrm{OH}$

Davydov, Leonid N., 1C

De Geronimo, Gianluigi, 08

De Mattia, Cristina, IF

Disch, C., 11

Dmitrenko, Valery V., 18

Doty, Patrick, 06

Douissard, P.-A., 12

Dowkontt, Paul, 08

Dragone, A., OV

Draper, Marie, 08

Duff, Martine C., 1K
Dupré, K., 12

Egarievwe, Alexander A., OY

Egarievwe, Stephen U., OY

Fasoli, Mauro, $1 \mathrm{~F}$

Feng, Patrick, 06

Fiederle, M., OG

Fisher, S. E., 02, ON

Fochuk, Petro M., 1C, 1G, 1H

Gao, Fei, OL

Grachev, Victor M., 18

Graff, R. T., 13

Grinyov, B. V., 1B

Groza, Michael, OB, 1K

Gu, G. D., 1N

Gul, R., 1N

Guo, Qingzhen, 08

Guss, Paul, OT, 1 A

Haines, Todd, $\mathrm{OH}$

Hales, Zaveon M., OY

Haller, G., OV

Hamann, E., OG

Hart, P., OV

Hasebe, Nobuyuki, 16

Hasi, J., OV

Hawrami, R., ON

Herbst, R., OV

Herrera, Elan, OB, OD

Herrmann, S., OV

Hobbs, C., 03

Hossain, Anwar, OF, OY, IN

House, David, 14

Howe, Russell, $\mathrm{OH}$

Hunter, S., 02, ON

James, Ralph B., OF, OY, 1C, 1G, 1H, IN

Kang, Dong-uk, IP

Kenney, C., OV

Kerisit, Sebastien, $\mathrm{OL}$

Khazhmuradov, Manap A., IC

Kim, Giyoon, 1P

Kim, H., 13

Kim, Kyeong J., 16

Kim, Myung Soo, 1P

Kindem, J., 02

Kislat, Fabian, 08

Kolopus, J. A., OJ

Koschan, M., 03

Kostioukevitch, S. A., 1B

Krawczynski, Henric, 08

Krishna, Ramesh M., $1 \mathrm{~L}$

Kruschwitz, Craig A., OC, OT 
Kuno, Haruyoshi, 16

Kusano, Hiroki, 16

Kutny, Vladimir E., 1C, 1G

Kwiatkowski, Kris, $\mathrm{OH}$

Lee, Daehee, IP

Li, Qi, OK, OM

Li, Shaorui, 08

Lindsey, A., 03

Liv, T., IN

Lu, Xinfu, OK

Lukosi, Eric, OB, OD

Lutz, Steve S., $\mathrm{OH}$

Lysetska, O. K., 1B

Malone, Robert, $\mathrm{OH}$

Mandal, Krishna C., 15, $1 \mathrm{~L}$

Mannan, Mohammad A., $1 \mathrm{~L}$

Markosyan, Gary, 06

Markovic, B., OV

Martin, T., 12

Matei, Liviu, OB, IK

Matias Lopes, José A., 16

Maurer, Richard, OT, 1 A

McKeever, S. W. S., 19

Meek, Thomas, OC

Melcher, C. L., 02, 03

Milburn, Robert, OD

Mitchell, Stephen, $\mathrm{OH}$

Momayezi, M., ON

Mones, Eleonora, IF

Mukhopadhyay, Sanjoy, OC, OT, IA

Nagaoka, Hiroshi, 16

Naito, Masayuki, 16

Neal, J. S., OJ

Nelson, A. J., 13

Nelson, K. E., ON

Nguyen, Khai $\vee_{\text {., }} 15$

Nikolic, R. J., 13

Nishimura, K., OV

Novikov, Alexander S., 18

Novikov, V., OG

Nykoniuk, Ye., 1G, 1H

Okwechime, Ifechukwude O., OY

Onyshchenko, G. M., 1B

Opolonin, O. D., 1B

Oyama, Yuki, 16

Pak, Rahmi O., $1 \mathrm{~L}$

Payne, S. A., 02, 0J, 0N, 13

Petrenko, Denis V., 18

Piven, L. A., 1B

Prange, Micah, $\mathrm{OL}$

Rack, A., 12

Radtke, M., 12

Ramey, J. O., OJ

Randles, M. H., ON

Rarenko, I., 1G, 1H

Reese, B., OV

Richardson, Dylan, OD

Riesemeier, H., 12

Rochet, X., 12

Rowe, E., OJ

Roy, U. N., OF, IN
Rybka, Alexandr V., 1C, 1G

Ryzhikov, V. D., 1B

Santodonato, Lovis, OD

Schreib, B., 14

Schneeloch, J., IN

Schwellenbach, David, OC

Seeley, Z. M., 02

Segal, J., OV

Shah, Kanai S., 06, 0N, 13

Shaver, Brandon, OC

Shibamura, Eido, 16

Shirwadkar, Urmila, 06

Shlyakhovyj, V., $1 \mathrm{H}$

Sholom, S., 19

Shustov, Alexander E., 18

Singh, N. B., 14

Sklyarchuk, O., $1 \mathrm{G}$

Sklyarchuk, Valery M., 1C, IG

Skrypnyk, Anna I., 1C

Smith, C. F., 1B

Solodovnikov, D., ON

Stand, L., 03

Stassun, Keivan, $\mathrm{OB}$

Stefanik, T., 02

Stevens, K. T., ON

Stowe, Ashley C., OB, OD

Swanberg, E. L., 02, 0N, 13

Tappero, R., OF

Thelin, P. A., ON

Tolbanov, O., OG

Tomada, A., OV

Tupitsyn, Eugene, OB

Tyazhev, A., OG

Ulin, Sergey E., 18

Uteshev, Ziyaetdin M., 18

Van Liew, Seth, OU

van Loef, Edgar V., 06

Vedda, Anna, $1 F$

Veronese, Ivan, IF

Vlasik, Konstantin F., 18

Voss, L. F., 13

Washington, Aaron L., $1 \mathrm{~K}$

Wei, H., 02, 03

Wesemann, V., 12

Wiggins, Brenden, OB, OD

Wihl, B. M., ON

Williams, Richard T., OK, OM

Wright, Jonathan S., $1 \mathrm{~K}$

Wu, Dangxin, OL

Xie, Yulong, OL

Yang, Ge, OF, 1H, $1 \mathrm{~N}$

Zajczyk, Anna, 08

Zakharchenko, Alexandr A., IC

Zakharuk, Z., 1G, $1 \mathrm{H}$

Zarubin, A., OG

Zhang, Ming, OU

Zhong, R., iN

Zhuravleva, M., 03 


\section{Conference Committee}

Program Track Chairs

Carolyn A. MacDonald, University at Albany (United States)

Ralph B. James, Brookhaven National Laboratory (United States)

Conference Chairs

Arnold Burger, Fisk University (United States)

Larry Franks, Consultant (United States)

Ralph B. James, Brookhaven National Laboratory (United States)

Michael Fiederle, Freiburger Materialforschungszentrum (Germany)

Conference Program Committee

Toru Aoki, Shizuoka University (Japan)

Fikri Aqariden, EPIR Technologies, Inc. (United States)

Jim E. Baciak Jr., University of Florida (United States)

David B. Beach, National Nuclear Security Administration

(United States)

Zane W. Bell, Oak Ridge National Laboratory (United States)

Lynn A. Boatner, Oak Ridge National Laboratory (United States)

Aleksey E. Bolotnikov, Brookhaven National Laboratory (United States)

Edith Bourret Courchesne, Lawrence Berkeley National Laboratory (United States)

Giuseppe S. Camarda, Brookhaven National Laboratory (United States)

Bill Cardoso, Creative Electron (United States)

Henry Chen, Redlen Technologies (Canada)

Nerine J. Cherepy, Lawrence Livermore National Laboratory (United States)

Jeffrey J. Derby, University of Minnesota (United States)

Kim F. Ferris, Pacific Northwest National Laboratory (United States)

Petro M. Fochuk, Yuriy Fedkovych Chernivtsi National University (Ukraine)

Jan Franc, Charles University in Prague (Czech Republic)

Fei Gao, Pacific Northwest National Laboratory (United States)

Zhong He, University of Michigan (United States)

Keitaro Hitomi, Tohoku University (Japan)

Alan Janos, U.S. Dept. of Homeland Security (United States)

Mercouri Kanatzidis, Northwestern University (United States)

Warnick J. Kernan, Pacific Northwest National Laboratory

(United States) 
Kelvin G. Lynn, Washington State University (United States)

Krishna C. Mandal, University of South Carolina (United States)

Robert D. McLaren, Consultant (United States)

Shariar Motakef, CapeSym, Inc. (United States)

Sanjoy Mukhopadhyay, National Security Technologies, LLC (United States)

Ian Radley, Kromek (United Kingdom)

Arie Ruzin, Tel Aviv University (Israel)

David J. Singh, Oak Ridge National Laboratory (United States)

Narsingh B. Singh, University of Maryland, Baltimore County (United States)

Michael R. Squillante, Radiation Monitoring Devices, Inc. (United States)

Ashley C. Stowe, Y-12 National Security Complex (United States)

Csaba Szeles, El Detection \& Imaging Systems (United States)

Sergey E. Ulin, National Research Nuclear University MEPhl (Russian Federation)

Peter E. Vanier, Brookhaven National Laboratory (United States)

Aaron L. Washington II, Savannah River National Laboratory (United States)

Richard T. Williams, Wake Forest University (United States)

Session Chairs

1 Scintillators I

Stephen A. Payne, Lawrence Livermore National Laboratory (United States)

2 CZTI

Robert D. McLaren, Consultant (United States)

3 Neutron Detectors

Arie Ruzin, Tel Aviv University (Israel)

4 Detector Materials I

Krishna C. Mandal, University of South Carolina (United States)

5 Scintillators II

Nerine J. Cherepy, Lawrence Livermore National Laboratory (United States)

6 CdTe and CZT

Utpal Roy, Brookhaven National Laboratory (United States)

7 Devices 1

Kelvin G. Lynn, Washington State University (United States) 
8 CZT II

Aleksey E. Bolotnikov, Brookhaven National Laboratory (United States)

9 Detector Materials II

Aleksey E. Bolotnikov, Brookhaven National Laboratory (United States)

10 Devices II

Art J. Nelson, Lawrence Livermore National Laboratory (United States)

Proc. of SPIE Vol. $9213921301-11$

Downloaded From: https://www.spiedigitallibrary.org/conference-proceedings-of-spie on 26 Apr 2023 Terms of Use: https://www.spiedigitallibrary.org/terms-of-use 
Proc. of SPIE Vol. $9213921301-12$

Downloaded From: https://www.spiedigitallibrary.org/conference-proceedings-of-spie on 26 Apr 2023 Terms of Use: https://www.spiedigitallibrary.org/terms-of-use 


\section{Introduction}

This book contains the proceedings of the SPIE Conference on Hard X-Ray, Gamma-Ray and Neutron Detector Physics XVI. The conference was held 18-20 August 2014 in San Diego, CA. The conference was organized into technical sessions on cadmium zinc telluride (CZT), cadmium telluride, scintillators, devices, neutron detectors, and alternative semiconductor detector materials. A poster session was also provided.

The purpose of the conference was to provide a forum for scientists and engineers from the detector development and user communities to present and evaluate the most recent results on x-ray, gamma-ray, and neutron detectors, and to discuss the requirements for a variety of radiation-sensing and imaging applications. The primary theme of the conference was on the development of improved semiconductor and scintillator radiation detectors and imaging arrays-which combine the advantages of room-temperature operation with the ability to spectrally resolve the energies of emitted $x$ - and gamma-rays. By eliminating the cryogen, new radiation-sensing instruments (such as spectrometers, gamma cameras and radiographic systems) can be manufactured that are portable, lightweight, easy to operate, and relatively maintenance-free. Recent research and development on detectors have resulted in measurable progress in the availability of single detectors and imaging arrays. In addition, recent reports of the material properties limiting the performance of semiconductor and scintillator detectors have provided new insights and directions to address deficiencies in the crystals and devices.

Despite the limitations on efficiency and relatively high cost of current roomtemperature semiconductor detectors and new emerging scintillators, they have been increasingly deployed in systems useful for medical diagnostics, space applications, safeguarding of nuclear materials, material identification, baggage scanning, position sensing, and gamma-ray spectroscopy. Although significant progress has occurred over recent years, there is still a pressing need to lower the cost of the detectors and to increase the efficiency of the detectors while improving their spectral performance.

A total of 64 presentations, including 15 posters, were provided at the conference. Although the number of attendees varied with the session and day of week, the attendance averaged approximately 50 people with a substantial fraction of those in attendance representing organizations outside of the United States.

This book provides detailed documentation describing a portion of the presentations. The editors hope that it will serve as an important record of the meeting, provide an update on the status of x-ray, gamma-ray, and neutron detector technology, and serve as a useful resource for those working in the field. 
The Conference Chairs would like to thank the session chairs and members of the Conference Program Committees, who offered their time to enlist the involvement of many researchers working in the field. We also express our indebtedness to all authors who contributed to the proceedings, and to the SPIE staff for their excellent cooperation and continuous support during the conference call, organization, and proceedings processes.

\section{Arnold Burger Larry Franks \\ Ralph B. James Michael Fiederle}

